\title{
Epistemological Beliefs and Mediating Role of Learning Approaches on Social Attitudes of SHS Students
}

\author{
M. Nur Ghufron
}

Institut Agama Islam Negeri Kudus, Indonesia

Received September 30, 2019; Revised December 18, 2019; Accepted December 25, 2019

Copyright $\subseteq 2020$ by authors, all rights reserved. Authors agree that this article remains permanently open access under the terms of the Creative Commons Attribution License 4.0 International License

\begin{abstract}
This study aims to examine the influence of epistemological beliefs which consists of belief in knowledge and belief in learning and mediating role of learning approaches on social attitudes of tolerance. Through multi-stage cluster sampling, there were 177 research respondents in Bae District, Kudus, Central Java, Indonesia. Data collection techniques used in this study were questionnaires in the form of scales. There are three types of scales used in the data collection process, namely the scale of tolerance, the scale of the approach to learning in religious education and the scale of epistemological beliefs. The results showed that belief in knowledge and belief in learning affected the deep and surface approaches. The deep approach can also be a variable of the mediating influence of epistemological beliefs on tolerance.
\end{abstract}

Keywords Epistemological Beliefs, Learning Approaches, Religious Education, Tolerance

\section{Introduction}

The phenomenon that is developing now is that tolerance is something that needs to be taken seriously. In fact, according to the Research and Development Center for Religious Life Research and Training Agency of the Ministry of Religion of the Republic of Indonesia (2010), tolerance is a basic element needed to foster mutual understanding and respect for differences, as well as being an entry point for the establishment of an atmosphere of dialogue and harmony between religious communities in society. To avoid conflicts between religious communities, tolerance must become a collective awareness of all groups of people, from the level of children, adolescents, adults, to parents, both students, employees, bureaucrats and students. More than that, the principles of tolerance must really work to regulate the life of the community effectively. One of the important sub-elements of the community in order to maintain the operation of the principles of tolerance is the SHS students.

Religious education in high school is one of the most important subject matter in instilling religious studies in the country of Indonesia. Religious education is the study of how to prepare students in believing, understanding, living and practicing religion through guidance, teaching, and/or training activities by paying attention to the demands to respect other religions in harmony relations between religious communities in the community whose main purpose is to realize national unity (Sabri, 1999). Through tolerance, it will be able to preserve the unity and integrity of the nation, support and succeed development, and eliminate inequalities. Tolerance enables people to treat others with respect and dignity, separating others from their beliefs and practices insofar as they are treated with impartiality, and individuals are valued as fellow human beings. This study aims to examine the model of the influence of epistemological beliefs which consists of belief in knowledge and belief in learning with the role of mediating the learning approach on student tolerance.

\section{Theoretical Basis}

\subsection{Epistemological Belief}

Epistemological beliefs, etymologically, epistemology comes from the Greek from the combination of the words "episteme" and "logos". Episteme means knowledge (Zerin, 1995), whereas logos usually shows theory or knowledge systemically. Research on epistemology suggests what is the source of knowledge, what is the reason? how do you determine the truth of that knowledge? and how to get knowledge? According to Schommer (1994) epistemology in educational psychology focuses on how individual beliefs about the nature of knowledge and the effect of knowing on cognitive processes.

In this study, epistemological beliefs are generally 
divided into beliefs about the nature of knowledge and beliefs about the nature of learning. Belief in the nature of knowledge consists of three dimensions, namely: First, that knowledge comes from authority/ people with expert knowledge such as lecturers or reference books, compared to their own logic and thinking. Second, that certain knowledge is absolute, unchanging and not tentative. The belief about the nature of learning consists of two dimensions, namely: First, quick learning. On this dimension, students who have a good learning approach believe that learning through a hard work process can increase the effectiveness of the learning approach they use. Second, innate ability or ability. Innate ability is the level of belief that the ability to learn is innate, rather than acquired or acquired (Jehng et al., 1993).

\subsection{Learning Approaches}

Educational experts and researchers have identified various variations and in general are almost equally related to learning approaches (e.g, Marton and Säljö, 1976; Biggs, Kember, \& Leung, 2001; Entwistle and Entwistle, 2003; Kember, Biggs \& Leung, 2004; Ramsden 2003). These approaches are expressed through interactions between factors brought by students into the learning context (eg, motivation, abilities, prior knowledge, interests, time), the learning context itself (eg, the way the material is presented by the teacher to students and the text), and, the most important is about how students interpret the way the material is presented. There is broad agreement about two approaches to learning, usually referred to as ' surface' and "'deep'.

The surface approach is when students are more dominant in reproducing information in accordance with the tasks or demands required, while the deep approach involves understanding effort (Chan, 2003), which in this approach is considered the right approach when students are required to learn to understand and apply the knowledge gained in the real world. On the other hand, surface approach is not appropriate for students who depend on memorization, avoid understanding and do not reflect learning experiences (Biggs et al., 2001; Tiwari et al., 2006), focuses on memorization, short-term retention, uncritical acceptance of ideas and facts, reliance on formulas to solve problems, and passive information (Entwistle, 1988; Ramsden, 1992). Meanwhile, in deep approach students look for meaning, apply ideas, look for patterns, and apply critical logic, while surface approach is motivated by the intention to overcome tasks that are often seen memorizing facts. Deep approach is associated with the need for meaningful learning experiences and trying to find answers to his curiosity, getting more pleasure from the whole learning process (Biggs \& Tang, 2011).

\subsection{Tolerance}

Tolerance is the attitude of allowing, acknowledging and respecting the beliefs of others without the need for approval. According to the Research and Development Center for the Religious Life of the Research and Development Agency of the Indonesian Ministry of Religion, (2010) explains that tolerance is an attitude of willingness to accept the diversity and freedom of religious beliefs and beliefs believed by other parties or groups. This can occur because of the existence and existence of a group, religion or belief, recognized or respected by other parties. In this tolerance all religious people must hold to the principle of agree in disagreement (agree on differences).

Tolerance between religious believers is not merely passive coexistence without mutual involvement with each other, but more than that, namely tolerance that is active and dynamic, which is actualized in the form of mutual respect and respect, do good and fair between people, and cooperate in build a harmonious, harmonious and peaceful society. The individual attitude of students with respect to differences may be largely determined by the epistemological beliefs students hold.

\subsection{The Effect of Epistemological Belief on Learning Approaches}

Related to the approach of student learning in religious education are closely related to the epistemological beliefs that students have. Various studies have shown that individual epistemological beliefs influence the use of approaches in learning (Cano, 2005; Chan, 2003; 2004; 2007; Phan, 2006; 2008; Tsai, 2000; Tsai \& Chuang, 2005; Bra ${ }^{\circ}$ ten \& Strømsø, 2006; Barnard et al., 2008). Hofer and Pintrich (1997) claim that epistemological beliefs play an important role in academic behavior, as it influences the use of techniques in learning. The results of Ghufron et al. (2017) show that epistemological beliefs influence students' learning and teaching concepts.

Chan (2007) argues that individuals who have low belief or even disbelief in knowledge structures such as simple structured knowledge will have little intrinsic orientation towards learning objectives, in valuing learning activities, in controlling learning and to feel that he can carry out a learning task. Likewise, students' beliefs about the stability of knowledge such as absolute, tentative or temporary knowledge and student's belief in the source of knowledge that knowledge comes from people who know better (omniscient), from the experience of people who have authority in conveying knowledge or from their own thoughts followed by various proofs.

Students who believe that the structure of knowledge consists of pieces that are not related to information, will likely use memorization techniques as learning techniques and not understanding techniques. The study also concluded that students who saw that the same unchanging and stable knowledge tended to use techniques to memorize scientific facts. In contrast to students who view dynamic knowledge, which will prioritize aspects of understanding information (Davis, 1997). Students who 
believe that knowledge is stable and can only be obtained through teaching authority, will have less understanding-oriented goals and more memorization-oriented (Bra ten and Strømsø, 2005). Therefore, understanding the role of epistemological beliefs both belief in knowledge and belief in learning is important in helping learners use effective learning approaches to achieve their academic goals, whether to use a deep or surface approach. Thus the hypothesis can be put forward:

H1. Belief in knowledge directly influences the deep approach.

H2. Belief in knowledge has a direct effect on the surface approach.

H3. Belief in learning has a direct effect on the deep approach.

H4. Belief in learning has a direct effect on the surface approach.

\subsection{Effects of Epistemological Belief on Tolerance}

Previous research confirms that individuals who uphold orthodox religious views tend to be dualistic (black and white) in their thinking (Desimpelaere et al., 1999), which is the basis for marking the initial stages of epistemological development (Perry, 1970). Epistemological belief has also been linked to the ability of individuals to analyze fallacy reasoning (Ricco, 2007). The results of Klaczynski's (2000) prove that school students who believe that knowledge is uncertain or uncertain, play a role in knowing the level of belief and need for data analysis, which is used to select opinions on social issues, with the aim of evaluating information objective. Students can reduce deviations in thinking and can understand opinions that contradict their opinions. Students who develop more sophisticated epistemological beliefs tend to have more friendly and tolerant perceptions in learning and criticizing than students who master more naive beliefs. When associated with an individual's religious position, epistemological beliefs will determine that position. Can it be tolerant in religion or just the opposite. Thus the hypothesis in this study can be proposed:

H5. Belief in knowledge directly influences tolerance.

H6. Belief in learning has a direct effect on tolerance.

\subsection{Influence of Religious Education Approach on Tolerance}

One of the important ways to foster tolerance is through religious education. It is recognized that the learning of religious education can make a student obediently intellectual and individually pray and or vice versa become just social prayer. Ideally religious education can foster pious souls individually and socially. As conveyed by the Minister of Religious Affairs of the Republic of Indonesia (in Yuliastuti, 2013) that religious education efforts in schools are expected to be able to form personal piety and social piety at the same time, so that religious education is expected not to (1) fostering a spirit of fanaticism, (2) fostering an intolerant attitude among students and the people of Indonesia, and (3) weakening religious harmony and national unity.

One effort to make students pious and tolerant is to use an appropriate learning approach. Learning approach is an attempt to obtain success and success in achieving goals. Learning approach is a learning activity that must be done by teachers and students so that learning objectives can be achieved effectively and efficiently. The results of several studies have shown that the learning approach has a positive effect on learning outcomes (Hasnora, et al., 2013) disciplinary attitudes (Killian \& Bastas, 2015), students' attitudes towards learning and academic attitudes (Taleb et al., 2013). The research results of the Research Center for Religious Life Research and Development Agency of the Ministry of Religious Affairs of the Republic of Indonesia, (2010) states that the learning outcomes of Religious education affect tolerance.

Learning objectives of religious education are achieved such that the material can be easily understood by students, be critical and able to connect with other experiences and ideas, integrate formal knowledge with individual experiences, and connect facts with conclusions (Ballantine et al., 2008; Baeten et al., 2008; Cano, 2007), then the learning approach was used which included an deep approach. In contrast to the surface approach, the focus is on memorizing religious education material, carrying out intellectual learning activities and having a material understanding in a passive way. If students have a more dominant to surface approach, it is possible to lower their diversity tolerance. Conversely, if students have deep approach that makes students more learning to understand religious education material rather than memorizing the material. Deep approach applies ideas, looks for patterns, and applies critical logic. Students who have a tendency to use the deep approach are likely to have a better tolerance for tolerance compared to students who use the surface approach.

H7. Deep approach has a direct effect on tolerance.

H8. Surface approach has a direct effect on tolerance.

\section{Research Method}

\subsection{Sampling}

The population in this study were all students or high school students (SMA), in Kudus Regency, Central Java Province, Indonesia. The sampling technique in this study is random sampling type multi-stage cluster sampling. Multi-stage cluster sampling in this study is to take samples in two or more stages because the population matches the purpose of this study, where the sample is high school students who are heterogeneous in terms of beliefs and religions and cannot be easily identified. Through 
multi-stage cluster sampling, sampling in this study was carried out with several stages, namely first, knowing all schools where students had a belief or religious variance. At this stage it is known that SMA 1 Bae, Kudus has students whose religion varies. Second, based on the number of classes in the school then the researcher took by drawing to get a research sample.

The number of samples obtained amounted to 177 students. The characteristics of the sample can be seen in table 1 .

Table 1. Characteristics of Research Samples

\begin{tabular}{|l|l|l|}
\hline Characteristics & N & Percentage \\
\hline Gender & & \\
\hline Male & 69 & 38 \\
\hline Female & 108 & 61 \\
\hline Grade & & \\
\hline Grade 10 & 23 & 12 \\
\hline Grade 11 & 69 & 38 \\
\hline Grade 12 & 85 & 48 \\
\hline Religion & & \\
\hline Islam & 124 & 70 \\
\hline Christian & 39 & 22 \\
\hline Catholic & 11 & 6 \\
\hline Hindu & 1 & 0.5 \\
\hline Buddha & 1 & 0.5 \\
\hline Age (years old) & & \\
\hline$<16$ & 23 & 12 \\
\hline $16-18$ & 151 & 85 \\
\hline$>18$ & 3 & 1.6 \\
\hline Total & 177 & 100 \\
\hline
\end{tabular}

\subsection{Research Instrument}

This epistemological belief is expressed by using a modified epistemological belief scale based on the epistemological belief scale developed by Jehng et al. (1993). Epistemological belief in this study is divided into two components of belief, namely; Belief in the nature of knowledge which includes aspects; (1) knowledge comes from people who know better/an expert (authority/expert knowledge), (2) knowledge that is certain (certain knowledge), and (3) an orderly process. The number of items of belief scale statement of knowledge amounted to 8 item statements. Examples of the items are; "I like the class where the teacher before teaching sets the learning program unit". The belief in learning includes; (1) learning quickly (quick learning) and (2) innate ability or ability. The number of aitem statement on the scale of belief in learning is 6 aitem statement. Examples of the items are; "students who have mediocre achievements during junior high school, will remain the same and have moderate achievement when they become high school students".

The deep approach is revealed by using a deep approach scale with components as the characteristics proposed by
Michael et al. (2013), namely learning is looking for meaning, linking ideas, using evidence and learning is to understand while the surface approach has the characteristics of learning related to remembering, learning is very dependent on the syllabus, fear of failure and teaching is simply transferring material. In total, the scale of the deep approach amounted to 20 items. Examples of the items are: "I usually begin to understand for myself the meaning of what must be learned". As a whole, the scale of the deep approach amounted to 20 items. The example items are; "I often wonder what I'm doing here is really useful."

The tolerance questionnaire was collected with indicators presented by the Research and Development Center for the Religious Life of the Indonesian Ministry of Religion Research and Development Agency (2010), namely one's awareness to respect, respect, allow, and allow the establishment, views, beliefs, beliefs, and provide space for the implementation of habits, behaviors, and other people's religious practices that are different or contrary to their own stance in order to build a better life together and social relations. The example items are; "Freedom of religion means that everyone, based on his own awareness and belief, freely embraces a religion without pressure, intimidation or coercion". "Willing to organize with friends of different religions".

Table 2. Results of validity and reliability of research instruments

\begin{tabular}{|l|l|l|}
\hline Variable & $\begin{array}{l}\text { Standarized } \\
\text { loading }\end{array}$ & Reliability \\
\hline Belief in Knowledge & & 0.78 \\
\hline knowledge is certain & 0.80 & \\
\hline knowledge from skilled people & 0.86 & \\
\hline knowledge is simple & 0.77 & \\
\hline Belief in Learning & & 0.63 \\
\hline default ability & 0.67 & \\
\hline quick learning & 0.86 & \\
\hline Deep Approach & & 0.74 \\
\hline look for meanings & 0.76 & \\
\hline improve ideas & 0.87 & \\
\hline using evidence & 0.63 & \\
\hline Surface Approach & & 0.76 \\
\hline learning is remembering & 0.93 & \\
\hline depends on syllabus & 0.88 & \\
\hline fear of failure & 0.77 & \\
\hline transferring means of teaching & 0.79 & \\
\hline Tolerance & & \\
\hline religious freedom & 0.56 & \\
\hline belief in religion & 0.44 & \\
\hline $\begin{array}{l}\text { freedom of rituals } \\
\text { and }\end{array}$ & 0.53 & \\
\hline social cooperation & 0.70 & \\
\hline & & \\
\hline
\end{tabular}


Validity test is done through unidimensionality test on each construct with confirmatory factor analysis. Based on the results of confirmatory analysis, it is found that the fit criteria value has been achieved well. The overall variable reliability results get $>0.60$ which can be stated that all the variables used have met the reliability requirements. A summary of the validity and reliability test results of each research instrument can be seen in table 2 .

\subsection{Data Analysis Technique}

The technique used to analyze the data in this study uses Structural Equation Models or also called Structural Equation Models. As for the analysis needs, the Analysis of MOment Structures (AMOS) software program is used.

\section{Results}

\subsection{Descriptive Statistic}

Before the model analysis is performed, the descriptive research data will be presented in advance for each scale. A statistical description of the research data is summarized in table 3 .

Table 3. Descriptive Statistic

\begin{tabular}{|l|l|l|l|l|l|}
\hline Variable & N & Min & Max & Mean & Std. Dev \\
\hline Belief in Knowledge & 177 & 3 & 27 & 14.18 & 6.149 \\
\hline Belief in Learning & 177 & 2 & 24 & 12.73 & 6.255 \\
\hline Deep Approach & 177 & 13 & 44 & 31.8 & 7.654 \\
\hline Surface Approach & 177 & 10 & 36 & 26.14 & 6.588 \\
\hline Tolerance & 177 & 65 & 158 & 112.46 & 22.034 \\
\hline
\end{tabular}

Table 3 displays the results of the belief variable in knowledge which has an empirical score of 14.18 , with a standard deviation of 6.149 , a belief variable in learning the empirical score of 12.73 , with a standard deviation of 6.255 , deep approach variable with an empirical average score of 31.8 , with a standard value deviation of 7.654 , the empirical mean surface approach variable value of 26.14 , with a standard deviation value of 6.588 and the tolerance variable religious empirical average score of 112.46 , with a standard deviation value of 22.034 .

\subsection{Test of Unidimensionality of Each Construct}

Before analyzing the structural equation model as a whole, the unidimensionality test of each construct is carried out first with confirmatory factor analysis. Based on the results of confirmatory analysis on each variable shows that the value of the fit criteria has been achieved well except for the variable of tolerance that still has not overall gotten the fit criteria. Likewise, the significance value of the estimated standardized parameter loading is all above 0.05 , except for the variable of tolerance in the indicator of religious belief, the estimated standardized parameter loading is below 0.05 so it can be said to be unfit. Therefore, in the following analysis these indicators were dropped or excluded from this research model.

\subsection{Hypothesis Testing}

The next step is to test theoretical data models with empirical data as a whole.

Based on the testing process, it was found that the criterion conditions in the form of Chi-Square 103, 105 $(\mathrm{DF}=95, \mathrm{p}=0.268), \mathrm{CMIN} / \mathrm{DF}=1.085, \mathrm{GFI}=0.936$, AGFI $=0.909$, TLI $=0.989$ and RMSEA $=0.022$ were fulfilled (see figure 1). Thus the relationship model can be said to be fit or the model can be fulfilled.

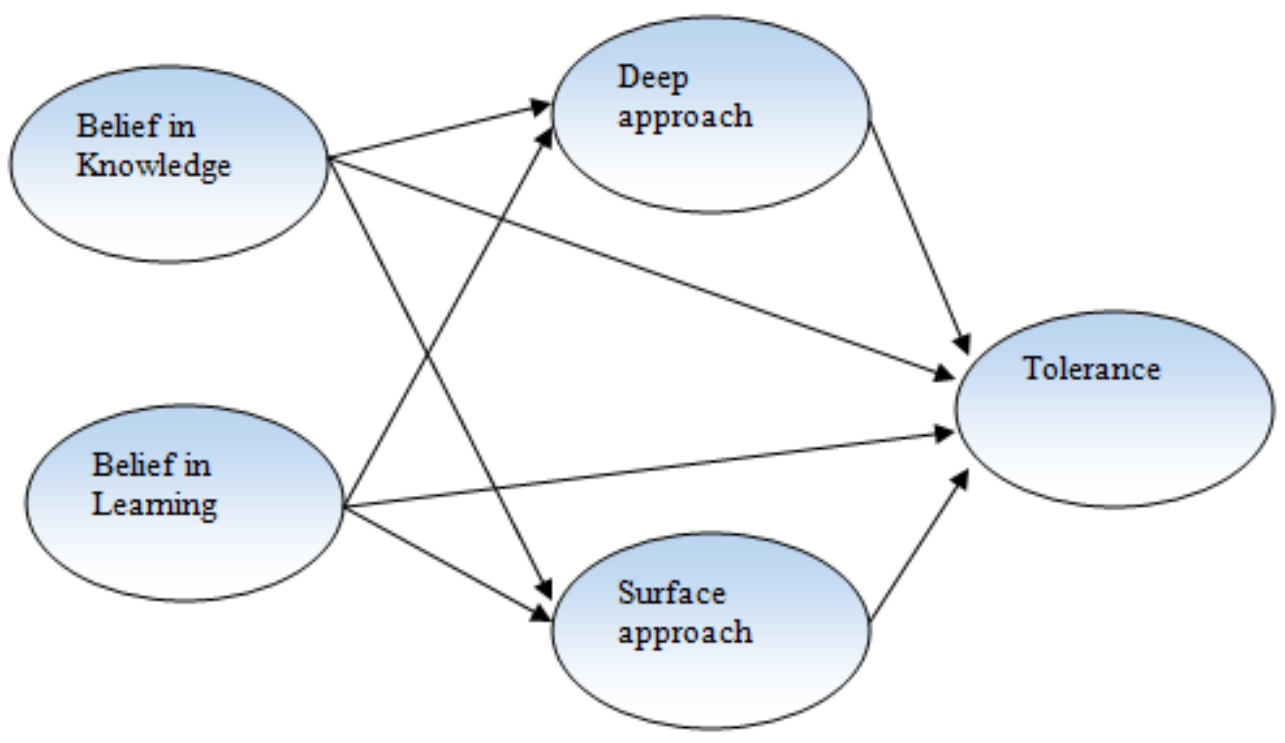

Figure 1. Full Research Model 
Thus it can be stated that the proposed model design as shown is not significantly different from empirical data. Based on these results, the researcher no longer needs to modify the model, so that the model used can be used in this study. This means that it can be stated there is a suitability of theoretical models with empirical data that can be accepted. Conclusions regarding the results of the first and second stage model tests can be seen in table 4 .

Table 4. Model test result

\begin{tabular}{|l|l|l|l|}
\hline Criteria & Cut-off-value & Results & Confirmation \\
\hline $\begin{array}{l}\text { Significance of } \\
\text { Chi-squared (p) }\end{array}$ & $>0.05$ & 0.268 & Fit \\
\hline RMSEA & $<0.05$ & 0.022 & Fit \\
\hline GFI & 0.9 & 0.936 & Fit \\
\hline AGFI & 0.9 & 0.909 & Fit \\
\hline TLI/ IFI & 0.95 & 0.989 & Fit \\
\hline
\end{tabular}

\subsection{Model Causality Test}

The results of the causality test regression weights based on the significance of the t-count with a probability value $(p)=0.05$ can be seen in table 5 .

Table 5. Results of Regression Weight Causality Test

\begin{tabular}{|l|l|l|l|l|}
\hline Hypotheses & Estimate & S.E. & C.R. & $P$ \\
\hline $\begin{array}{l}\text { Belief in knowledge } \rightarrow \\
\text { deep approach }\end{array}$ & -1.094 & 0.171 & -6.444 & 0.000 \\
\hline $\begin{array}{l}\text { Belief in knowledge } \rightarrow \\
\text { surface approach }\end{array}$ & 0.311 & 0.066 & 4.725 & 0.000 \\
\hline $\begin{array}{l}\text { Belief in learning } \rightarrow \text { deep } \\
\text { approach }\end{array}$ & -0.160 & 0.081 & -1.971 & 0.049 \\
\hline $\begin{array}{l}\text { Belief in learning } \rightarrow \\
\text { surface approach }\end{array}$ & 0.090 & 0.032 & 2.798 & 0.005 \\
\hline $\begin{array}{l}\text { Belief in knowledge } \rightarrow \\
\text { tolerance }\end{array}$ & -0.193 & 0.220 & -0.877 & 0.381 \\
\hline $\begin{array}{l}\text { Belief in learning } \rightarrow \\
\text { tolerance }\end{array}$ & 0.052 & 0.078 & 0.664 & 0.507 \\
\hline $\begin{array}{l}\text { Surface approach } \rightarrow \\
\text { tolerance }\end{array}$ & -0.299 & 0.272 & -1.097 & 0.273 \\
\hline $\begin{array}{l}\text { Deep approach } \rightarrow \\
\text { tolerance }\end{array}$ & 0.601 & 0.171 & 3.517 & 0.000 \\
\hline $\begin{array}{l}\text { Surface approach } \rightarrow \\
\text { tolerance }\end{array}$ & -0.299 & 0.272 & -1.097 & 0.273 \\
\hline
\end{tabular}

Further explanation of the regression weight evaluation analysis can be explained that the belief in knowledge significantly affects the deep approach and the surface approach, because the significance of the $t$-count is smaller than the probability $\leq 0.05$. Belief in learning significantly influences the deep approach and surface approach because the significance of the t-test is smaller than the probability $\leq 0.05$. Belief in knowledge and belief in learning does not affect tolerance because the significance of the t-test is greater than the probability $>0.05$. The deep approach significantly influences tolerance because the significance of the t-test is smaller than the probability $\leq 0.05$. The surface approach does not affect tolerance because the significance of the t-test is greater than the probability $>0.05$.

\subsection{Analysis of Direct Effects, Indirect Effects and Total Effects}

The magnitude of the effect of each latent variable directly (standardized direct effect) and indirectly (standardized indirect effect) and total effect (standardized total effect) are summarized in Table 6 .

Table 6. Direct Effects. Indirect Effects and Total Effects

\begin{tabular}{|l|l|l|l|}
\hline Variable & $\begin{array}{l}\text { Direct } \\
\text { Effects }\end{array}$ & $\begin{array}{l}\text { Indirect } \\
\text { Effects }\end{array}$ & $\begin{array}{l}\text { Total } \\
\text { Effects }\end{array}$ \\
\hline $\begin{array}{l}\text { Belief in knowledge } \rightarrow \\
\text { deep approach }\end{array}$ & -0.617 & 0.000 & -0.617 \\
\hline $\begin{array}{l}\text { Belief in learning } \rightarrow \text { deep } \\
\text { approaches }\end{array}$ & -0.181 & 0.000 & -0.181 \\
\hline $\begin{array}{l}\text { Belief in knowledge } \rightarrow \\
\text { surface approach }\end{array}$ & 0.487 & 0.000 & 0.487 \\
\hline $\begin{array}{l}\text { Belief in learning } \rightarrow \\
\text { surface approach }\end{array}$ & 0.281 & 0.000 & 0.281 \\
\hline $\begin{array}{l}\text { Belief in knowledge } \rightarrow \\
\text { tolerance }\end{array}$ & -0.108 & -0.421 & -0.529 \\
\hline $\begin{array}{l}\text { Belief in learning } \rightarrow \\
\text { tolerance }\end{array}$ & 0.059 & -0.138 & -0.080 \\
\hline $\begin{array}{l}\text { Deep approach } \rightarrow \\
\text { tolerance }\end{array}$ & 0.598 & 0.000 & 0.598 \\
\hline $\begin{array}{l}\text { Surface approach } \rightarrow \\
\text { tolerance }\end{array}$ & -0.107 & 0.000 & -0.107 \\
\hline
\end{tabular}

Analysis of the magnitude of the influence of each variable can be explained in detail that the belief in knowledge has a direct effect (negative) on deep approach strategies of -0.617 and has a direct positive effect on the surface approach of 0.487 and a direct negative effect on tolerance of -0.108 . The belief in learning has a direct negative effect on deep approach strategies of -0.181 and a direct positive effect on the surface approach of 0.281 and a direct (negative) effect on tolerance of 0.059 . The deep approach has a direct negative effect on tolerance of -0.598 and the surface approach has a direct negative effect on the attitude of tolerance of -0.107 . Belief in knowledge influences tolerance by -0.108 , and indirect effect on tolerance through deep approach and surface approach of -0.421 , and a total effect of -0.529 . Belief in learning has an effect on tolerance of 0.059 , and an indirect effect on tolerance through deep approach and surface approach of -0.138 , and a total effect of -0.107 .

\section{Discussion}

The SEM results show that the belief in knowledge has a significant negative relationship to the deep learning approach. In other words, the higher the belief in knowledge, the lower the deep learning approach. It was also found that, belief in knowledge has a significantly positive relationship to the surface learning approach. That is, the higher the confidence in knowledge, the higher the surface learning approach. 
Students who have confidence in high knowledge show that students have confidence in knowledge that is certain, absolute, permanent, knowledge is simple or fragmented or not related to other knowledge and knowledge can only be obtained through experts. Such conditions will make students tend to learn done by orienting on memorization. Learning is interpreted as memorizing Islamic Education subject matter. The more memorization is considered as the better the learning. Conversely, students who have low confidence in knowledge show that students believe that knowledge can develop, knowledge is related to concepts with others, and knowledge can not only be obtained from an expert alone, but can be obtained from one's own thinking by reinforced various evidence. Such conditions will make students tend to learn done by orienting on understanding. Learning is by understanding Islamic Education subject matter.

The results of this study also found that, belief in learning had a significant negative effect on the deep learning approach, and had a significant positive effect on the surface learning approach. It is said that confidence in learning is high when students believe that learning can be done quickly and learning is very dependent on the innate abilities of students. Conversely, trust in learning is low when students believe that learning is a process that students do, it takes hard work to be able to produce a certain ability. Students who tend to believe that learning can be done quickly and abilities are innate tend to use a surface learning approach. Conversely, students who believe that learning is a process and need hard work tend to increase the effectiveness of the learning strategies used, so that the deep learning approach students use.

Belief in knowledge influences the deep learning approach and the surface learning approach. Likewise trust in learning also influences deepening learning approaches and surface learning approaches. Overall, the results of this study are consistent with previous research (Cano, 2005; Chan, 2003; 2004; 2007; Paulsen \& Feldman, 1999; Paulsen \& Gentry, 1995; Phan, 2006; 2008; Tsai, 2000; Tsai \& Chuang , 2005; Bra ${ }^{\circ}$ ten \& Strømsø, 2006; Barnard et al., 2008). The results of this study are also consistent with the results of a meta-analysis study conducted by Ghufron (2009) that epistemological beliefs can be used as individual predictors in the selection of learning approaches used.

This research also results that only the deep learning approach is proven to influence tolerance. The higher the students use the deep learning approach, the higher the tolerance they have. The results of this study are in accordance with previous studies such as the results of the Research and Development Center for the Research and Development of the Religious Life of the Ministry of Religion of the Republic of Indonesia (2010) stating that religious education learning outcomes affect tolerance. Through a good understanding of religious education, a student has an appreciation of the profound aspects of religion so as to make students more able to respect others more humanely. In other words, it is the depth of religion that makes one more tolerant of others. In religious tolerance, it takes honesty, greatness of the soul, wisdom and responsibility, to foster a feeling of solidarity.

The surface approach variable has a direct and negative influence on tolerance of -0.299 . However, when viewed from the significance value of t-count, the value is greater than 0.05 , so it can also be said that the surface approach does not affect tolerance. This is possible because the theoretical foundation of this research is not strong regarding the effect of the relationship between these variables and the small number of samples for analysis using structural equation models.

The results of this study also found that belief in knowledge and belief in learning did not directly influence tolerance. However, if mediated the deep approach will look influential. Solimun (2003) argues that the coefficient of indirect effect is obtained from the product of the coefficient of direct influence of independent variables on mediating variables with the direct effect coefficient of mediating variables on dependent variables. In addition, the significance test is obtained from the criteria if both direct effects are significant then the indirect effect is also significant, conversely if one of the two direct effects is not significant then the indirect effect is also not significant. Based on the calculation results it is known that the deep approach and the surface approach (as mediating variables) affect tolerance only on the deep approach so it can also be stated that only the deep approach can be the mediating variable of the independent variable on the dependent variable. Thus it can be stated that, the influence of belief in knowledge and belief in learning towards tolerance indirectly through mediated deep approaches can be accepted while those mediated in surface approaches cannot be accepted. The variable influence of belief in knowledge and learning beliefs on tolerance indirectly through the surface approach mediated by the surface approach cannot be accepted.

The results of this study may be possible given that as expressed by Altemeyer (2005) that, a person holds a fundamentalist religion from an early age to get religious learning by getting teachings not only absolute (certain and simple knowledge), but these teachings must also be learned from more people know (religious experts/leaders) as a source of religious knowledge. Furthermore, Altemeyer (2005) reports that religious teachings for fundamentalists directly strengthen authoritarian attitudes. Thus this can happen, when viewed from the nature of religious teaching which emphasizes salvation based on the good relationship between the self of "an individual" with his "God", does not put good pressure between "individuals" with "individuals of each other". By implication, education and teaching of religion make an apologetic and polemical approach, driven by exclusive theological attitudes so that religious studies in educational 
institutions lead to a dualistic spirit (right and wrong) (Susilo \& Dalimunthe, 2019). In addition, a key component of individuals who do not have high tolerance is dependence and respect for the scriptures intellectually to produce a comprehensive meaning system or worldview (Hood, Hill, \& Williamson, 2005), which implies that regardless of whether the leader religion has a depth of knowledge/is considered omniscient but more on the side of conformity with sacred texts. In other words, religious fundamentalists can be reflected in epistemology which individuals believe that knowledge in the domain of religion is certain, simple, and comes from an infallible, authority that knows everything.

The results of this study are also in accordance with the opinion of Kuhn (1999) which states that basically knowledge is factual, and certain. Individuals with low tolerance tendencies also show a tendency to show general belief outside the realm of religion that knowledge is certain, comes from omniscient authority and that learning occurs quickly or not at all. Hathcoat's (2008) research results show that high fundamentalists have a tendency to believe that knowledge is certain, comes from omniscient authority, and that learning occurs quickly or not at all. The results of Tabak and Weinstock's research (2008) on elementary school students in Israel, show that students in the religion program hold absolute epistemological beliefs, because religious programs include disciplines that are difficult to question.

\section{Conclusions}

Based on the testing process, it is obtained that the design model proposed in this study is significantly consistent with empirical data. It can also be stated that there is a compatibility between theoretical models and empirical data. The results of this study indicate that belief in knowledge influences the deep and surface approaches. Belief in learning also influences the deep and surface approaches. More specifically, the research findings confirm that belief in knowledge influences the deep and surface approaches. The variable of belief in learning also influences the deep approach and the surface approach. The variable of belief in knowledge and belief in learning does not directly influence the attitude of tolerance. The variable of the deep approach significantly influences the attitude of tolerance while the variable of the surface approach does not affect the attitude of tolerance. The results of this study also showed that only deep approach variable could be a mediating variable between belief in knowledge and belief in learning towards tolerance.

Thus, it can be stated that, the influence of belief in knowledge on tolerance indirectly through mediated deep approaches can be accepted while those mediated in surface approaches cannot be accepted.

\section{REFERENCES}

[1] Altemeyer, B. (2005). Fundamentalism and authoritarianism. In Handbook of psychology of religion and spirituality (pp. 378-393). New York: Guilford Press.

[2] Altemeyer, B., \& Hunsberger, B. (1992). Authoritarianism, religious fundamentalism, quest, and prejudice. 2 , 113-133.

[3] Altemeyer, B., \& Hunsberger, B. (2004). "A Revised Religious Fundamentalism Scale: The Short and Sweet of it." International Journal for the Psychology of Religion 14: 47-54.

[4] Ballantine, J. A., Duff, A., \& McCourt Larres, P. (2008). Accounting and business students' approaches to learning: A longitudinal study. Journal of Accounting Education, 26(4), 188-201.

[5] Barkun, M. (2004). Religious violence and the myth of fundamentalism. In L. Weinberg and A. Pedahzur (Eds.), Religious fundamentalism and political extremism (pp. 55-70). London: Frank Cass.

[6] Barnard, L., Lan, Y.L., Crooks, M.S.dan Paton, V.O. (2008). The Relationship between Epistemological Beliefs and Self-regulated Learning Skills in the Online Course Environment. MERLOT Journal of Online Learning and Teaching. 4, 261-266

[7] Biggs, J. B. (2001). Enhancing learning: a matter of style or approach? (73-102). In: R. J. Sternberg \& Lf F. Zhang (Eds.) Perspectives on thinking, learning, and cognitive styles. Mahwah, NJ: Erlbaum.

[8] Biggs, J.B., \& Tang, C. (2011). Teaching for quality learning at university: What the student does (4thed.). Maidenhead: Open University Press.

[9] Biggs, J.B., Kember, D., \& Leung, D.Y.P. (2001) The Revised Two Factor Study Process Questionnaire: R-SPQ-2F. British Journal of Educational Psychology. 71, 133-149

[10] Bra ${ }^{\circ}$ ten, I. \& Strømsø, H.I. (2006). Epistemological beliefs, interest, and gender as predictors of Internet-based learning activities. Computers in Human Behavior, 22, 1027-1042.

[11] Cano, F. (2005). Epistemological beliefs and approaches to learning: Their change through secondary school and their influence on academic performance. British Journal of Educational Psychology, 75, 203-221.

[12] Chan, K. (2003). Hong Kong teacher education students' epistemological beliefs and approaches to learning. Journal Research in Education, $69,36-50$

[13] Chan, K. (2004). Preservice Teachers' Epistemological Beliefs and Conceptions about Teaching and Learning: Cultural Implications for Research in Teacher Education. Australian Journal of Teacher Education, 1, 1-13

[14] Chan, K. (2007). Hong Kong Teacher Education student's Epistemological Beliefs and their Relations with Conceptions of Learning and Learning Strategies. The Asia Pacific-Education Researcher, 16, 199-214. 
[15] Davis, E.A. (1997). Students. Epistemological Beliefs about Science and Learning. Paper presented at the Annual Meeting of the American Educational Research Association, Chicago, IL.

[16] Desimpelaere, P., Sulas, F., Duriez, B., \& Hutsebaut, D. (1999). Psycho-Epistemological Styles and Religious Beliefs. The International Journal for the Psychology of Religion, 9(2). 125-137

[17] Entwistle, N.(1988).Styles of Learning and Teaching,David Fulton.

[18] Entwistle, N., \& Entwistle, D. (2003). Preparing for examinations: The interplay of memorizing and understanding, and the development of knowledge objects. Higher Education Research and Development, 22, 19-42.

[19] Ghufron, M. N., Indiyati Eko, P \& Cahyani, B, H. (2013). Model Struktural Hubungan Antara Kepercayaan Epistemologis dengan Konsepsi Tentang Belajar dan Mengajar Mahasiswa. Inferensi, Jurnal Penelitian Sosial Keagamaan, 11,1, 51-74

[20] Ghufron, M. Nur (2009). Hubungan antara Kepercayaan Epistemologi dan Pendekatan Belajar: Studi Metaanalisis. Jurnal Psikologi. 36, 130-143

[21] Hasnora, H. N., Ahmad, Z. \& Nordin, N. (2013). The Relationship between Learning Approaches and Academic Achievement among Intec Students, Uitm Shah Alam. Procedia - Social and Behavioral Sciences 90. 178 - 186

[22] Hathcoat, J., D. (2008). Religious Fundamentalists' Epistemic Beliefs and Relationship to Right-Wing Authoritarianism. Unpublished Thesis. Oklahoma State University.

[23] Hofer, B.K. (2001). Personal epistemology research: Implications for learning and teaching. Educational Psychology Review, 133, 353-382.

[24] Hofer, B.K. dan Pintrich, P.R. (1997) The Development of Epistemological Theories: Beliefs about Knowledge and Knowing and Their Relation to Learning. Review of Educational Research, 67, 88-140

[25] Hood, R. W., Hill, P. C, \& Williamson, W. P. (2005). The psychology of religious fundamentalism. New York and London: Guilford Press.

[26] Jehng, J.C., Johnson, S.D. \& Anderson, R.C. (1993). Schooling and students' epistemological beliefs about learning. Contemporary Educational Psychology, 18, 23-25.

[27] Kember, D., Biggs, J., \& Leung, D. Y. P. (2004). Examining the multidimensionality of approaches to learning through the development of a revised version of the Learning Process Questionnaire. British Journal of Educational Psychology, 74, 261-280.

[28] Killian, M. and Bastas, H. (2015). The Effects of an Active Learning Strategy on Students' Attitudes and Students' Performances in Introductory Sociology Classes. Journal of the Scholarship of Teaching and Learning, Vol. 15, No. 3 , June 2015, pp. 53-67. doi: 10.14434/josotl.v15i3.12960

[29] Klaczynski, P.A. (2000). Motivated scientific reasoning biases, epistemological beliefs, and theory of polarization: A two-process approach to adolescent cognition. Child
Development, 71, 1347-1366.

[30] Kuhn, D. (1999). A developmental model of critical thinking. Educational Researcher, 28, 16-25.

[31] Marton, F. \& Säljö, R. (1976). On qualitative differences in learning I: Outcome and process. British Journal of Educational Psychology, 46, 4-11.

[32] Perry, W. G. Jr. (1970). Forms of intellectual and ethical development in the college years: A scheme. New York: Holt, Rinehart \& Winston.

[33] Phan, P. H. (2006). Examination of student learning approaches, reflective thinking and epistemological belief. Electronic Journal of Research in educational Psychology, 4, 577-610

[34] Phan, P. H. (2008). Multiple regression analysis of epistemological belief, learning approaches and self regulated. Electronic Journal of Research in educational Psychology, 6, 157-184

[35] Puslitbang Kehidupan Keagamaan Badan Litbang dan Diklat Kementerian Agama RI (2010) Toleransi Beragama Mahasiswa (Studi tentang Pengaruh Kepribadian, Keterlibatan Organisasi, Hasil Belajar Pendidikan Agama, dan Lingkungan Pendidikan terhadap Toleransi Mahasiswa Berbeda Agama pada 7 Perguruan Tinggi Umum Negeri). Jakarta: Badan Litbang dan Diklat Kementerian Agama.

[36] Ramsden, P (1992) Learning to Teach in Higher Education. London: Routledge.

[37] Ramsden, P. (2003). Learning to teach in higher education (2nd ed.). London: RoutledgeFalmer.

[38] Ricco, R.B. (2007). Individual differences in the analysis of informal reasoning fallacies. Contemporary Educational Psychology, 32, 459-484.

[39] Sabri,M. A. (1999) Ilmu Pendidikan, Jakarta: CV Pedoman Ilmu Jaya.

[40] Schommer, M. (1990). Effects of beliefs about the nature of knowledge on comprehension. Journal of Educational Psychology, 82, 498-504.

[41] Schommer, M. (1994). An emerging conceptualization of epistemological beliefs and their role in learning. In R. Garner \& P.A. Alaxander (Eds)., Beliefs about text and instruction with text. (pp. 25-40). Hillsdale, NJ: Lawrence Earlbaum Associates Inc.

[42] Schommer, M. (1994). Synthesizing epistemological belief research: Tentative understandings and provocative confusions. Educational Psychology Review, 6, 293-319

[43] Schommer, M. A. (2004). Explaining the Epistemological Belief System: Introducing the Embedded Systemic Model and Coordinated Research Approach. Educational Psychologist, 39, 19-29

[44] Schraw, G. (2001). Current Themes and Future Directions in Epistemological Research: A Commentary. Educational Psychology Review, 13, 451-463.

[45] Solimun (2003) Multivariate Analysis Structural Equation Modelling (SEM) Lisrel dan Amos Aplikasi di Manajemen, Ekonomi Pembangunan, Psikologi, Sosial, Kedokteran dan Agrokompleks. Malang: Universitas Negeri Malang. Hanin 
Naziha Hasnora, Zaiton Ahmadb, Norshidah Nordin, (2013)

[46] Spilka, B., Hood, R.W., Jr., Hunsberger, B., Gorsuch, R. (2003). The psychology of religion: an empirical approach. New York, NY: The Guilford Press.

[47] Susilo, S., \& Dalimunthe, R. P. (2019). Moderate Southeast Asian Religious education as a Parent Culture in Deradicalization: Urgencies, Strategies, and Challenges. Religions, 10(1), 45.

[48] Tabak, I. \& M. Weinstock (2008). A Sociocultural exploration of epistemological beliefs. InM. S. Khine (Ed.). Knowing, knowledge and beliefs: Epistemological studies across diverse cultures. Amsterdam, Netherlands: Springer.

[49] Taleb, M., B., Ghanbari, A., Yousefi, Z., Botlani, S. (2013) Cognitive Strategies Instruction: Attitudes toward Learning and Academic Functioning In Science. Bulgarian Journal of Science and Education Policy (BJSEP), Vol 7, (1), 104-120

[50] Tiwari, A., Chan, S., Wong, E., Wong, D., Chui, C., Wong, A., \& Patil, N. (2006). The effect of problem-based learning on students' approaches to learning in the context of clinical nursing education. Nurse Education Today, 26 (5), 430-438.

[51] Tsai, C. C. (2000). Relationships between student Scientific epistemological beliefs and perceptions of constructivist learning environments. Educational Research, 42, 193-205

[52] Tsai, C.C. dan Chuang, S.C. (2005). The correlation between epistemological beliefs and preferences toward Internet-based learning environments. British Journal of Educational Technology, 36, 97-100. Jou

[53] Yuliastuti, E. (2013) Peningkatan Motivasi Belajar Pendidikan Agama Islam Materi Al-Qur'an Melalui Model Pembelajaran Tutor Sebaya Pada Siswa Kelas X/4 SMA Negeri 1 Ngemplak Kabupaten Boyolali Tahun Pelajaran 2012/2013. Naskah Publikasi. Fakultas Agama Islam, Universitas Muhammadiyah Surakarta.

[54] Zerin, E. (1995). Methods of Human Knowing. Transactional Analysis Journal, 25, 150-155 